\title{
Bibliography
}

\section{Manuscript Sources}

Antiquae consuetudines Majoris monasterii prope Turones. See Paris, Bibliothèque Nationale, MS. lat. 12879.

Auxerre, Treasury of the Cathedral

MS. 6-Missal from Saint-Julian of Tours, copied in the second half of the thirteenth century.

Charleville, Bibliothèque Municipale

MS. II 7-Twelfth-century collection from the Cistercian abbey of Signy.

Fols. 79-128 constitute a collection concerning the cult of Saint Martin and the Abbey of Marmoutier. It includes the De reversione beati Martini a Burgundia, four miracles from the collection attributed to Herbernus, sections of the De commendatione Turonicae provinciae dealing with the history of Marmoutier, the De rebus gestis in Majori monasterio, and the Liber de restructione Majoris monasterii. Under a different rubric, but immediately following this section (fols. $128-39^{v}$ ), is the Historia septem dormientium (Majoris monasterii). (See Source Appendix, I-B, I-C, I-D, I-E.)

Paris, Archives Nationale

Le Service des Sceaux, D. 7599-Seal of Aubrey Cormut, dean of Saint-Martin 1229-36.

Paris, Bibliothèque Nationale

MS. lat. I-The Vivien Bible, ninth century.

MS. lat. $943 \mathrm{I}$ - Sacramentary from Marmoutier, copied af ter 1096.

MS. lat. 9434-Eleventh-century missal from Saint-Martin of Tours.

MS. lat. I24I2-Late twelfth-century collection of sermons from Marmoutier.

MS. lat. 12875-Contains (at fol. 607) original parchment of charter written in I I Is establishing ceremonial ties between Marmoutier and Saint-Martin.

MS. lat. 12878-79-Dom Edmond Martène's preuves for his Histoire de l'abbaye de Marmoutier. Includes ( 12979 , fols. 86- I $18 \mathrm{v}$ ) the only surviving copy of the Antiquae consuetudines Majoris monasterii, as well as copies of other documents that have been lost. Early eighteenth century. 
MS. lat. 13899-Fif teenth- or early sixteenth-century copy of an earlicr manuscript from Marmoutier, which began with an inscription saying it was copied in I I 87. Nevertheless, this manuscript contains later material as well. MS. lat. I 5067-Fourteenth-century collection from Marmoutier.

\section{Collection Baluze}

MS. 76-Extracts from the archives of Saint-Martin of Tours, copied primarily by Etienne Baluze in the late seventeenth and early eighteenth centuries. Includes copies of medieval originals that have been lost.

MS. 77-Extracts from cartularies of Marmoutier and Saint-Martin, copied primarily by Etienne Baluze. Includes copies of medieval originals that have been lost.

\section{Collection Housseau (or Touraine)}

Late seventeenth- and early eighteenth-century collection completed by Dom Housseau, which includes copies of medieval documents that have been lost. MS. 3, 4, 5, 6, 20.

\section{Rouen, Bibliothèque Municipale}

MS. 243-Eleventh-century breviary from Marmoutier.

\section{Tours, Archives d'Indre-et-Loire}

$\mathrm{G}_{3} 8 \mathrm{I}$ - Eighteenth-century inventory of property rights containing summaries of medieval documents, many of which are now lost.

\section{Tours, Bibliothèque Municipale}

Missal from the Petit Séminaire-Eleventh-century missal from Marmoutier. MS. 94-Collection of texts copied in the late fourteenth century, primarily by Laurent de la Faye. Includes, at fols. $37-39^{v}$, the Statutes of the Priories of Marmoutier.

MS. I 53-Early thirteenth-century breviary used at Marmoutier.

MS. I 84-Parts of several sacramentaries from Tours that were copied in the late ninth and tenth centuries.

MS. 193-Missal, copied about I I77-87 for Saint-Martin of Tours.

MS. 196-Eleventh-century sacramentary from Saint-Martin, used at Marmoutier.

MS. I 98-Missal from Villeloin in Touraine, copied in the second half of the thirteenth century.

MS. I018-Eleventh-century lectionary from Saint-Martin, concerning Saint Martin and his cult.

MS. I02I-Thirteenth-century lectionary from Saint-Martin, concerning Saint Martin and his cult.

MS. 1023-Fifteenth-century collection from Saint-Martin, primarily concerning Saint Martin and his cult.

MS. I 294-95-Celeberrimae Sancti Martini ecclesiae historia. Originally printed by Raoul Monsnyer, then augmented with handwritten additions by Michel Vincent in the early eighteenth century. Contains copies of medieval documents that are now lost. 


\section{Primary Sources}

Abbo, Monk of Saint Germain. "De bello Parisiaco." Edited and translated by

Henri Waquet. In Le siège de Paris par les Normands. Paris: Belles Lettres, 1942.

Abbo of Fleury. Epistolae. PL 139:417-62.

Acta S. Florentii dubiae fidei auctore anonymo seculo IX scripta. In Acta sanctorum, September, 6:428-32.

Adam of Perseigne. Correspondance d'Adam, Abbé de Perseigne. Edited by Jean Bouvet. Archives historiques du Maine, I 3. Le Mans: Société Historique de la Province du Maine, I95I-62.

Epistolae. PL 21 I:579-694.

Lettres. Edited and translated by Jean Bouvet. Sources Chrétiennes 66.

Paris: Cerf, 1960.

Alcuin. "De vita S. Martini Turonensis." PL 101:657-62.

"Sermo de transitu S. Martini." PL Ior:662-64.

An Alphabet of Tales: An English Fifteenth-Century Translation of the Alphabetum Narrationum of Etienne de Besançon. Edited by M. M. Banks. Early English Text Society I26. London: K. Paul, Trench, Truber, 1904-5.

"Analekten zur Geschichte des Reformpapsttums und der Cluniazenser." Edited by Johannes Ramackers. Quellen und Forschungen aus Italienischen Archiven und Bibliotheken, Herausgegeben von Preussischen Historischen Institut in Rom 23(193 I32): 22-52.

Anonymous of Pavia. Liber de laudibus civitatis Ticinensis. Edited by L. Muratori. In Rerum Italicarum scriptores, vol. II, part I. 32 vols. in II9. New revised edition, under the direction of Giosuè Carducci, Vitorio Fiorini. Città di Castello: S. Lapi, 1900-1975.

Arnulphus, Archbishop of Tours. "Decretum." Edited by Joannes Maan. In Sancta et metropolitana ecclesia Turonensis sacrorum pontificum suorum ormata virtutibus et sanctissimis conciliorum institutis decorata, 248-49. Tours, I667.

Augustine of Hippo. Sancti Augustini Confessionum libri XIII. Edited by Lucas Verheijen. Corpus Christianorum, Series Latina 27. Turnhout: Brepols, I98I. Translated by R. S. Pine-Coffin. Harmondsworth, England: Penguin Books, I96I.

Baudry of Bougueil. Les oeuvres poétiques de Baudri de Bourgueil, 1046-1130. Edited by Phyllis Abrahams. Paris: H. Champion, 1926.

Bernard of Angers. Liber miraculorum Sancte Fidis. Edited by Auguste Bouillet. Paris: A. Picard, I 897.

Bibliotheca rerum Germanicarum. Edited by P. Jaffé, Wilhelm Wattenbach, and Ernst Ludwig Dümmler. 6 vols. Berlin: Weidmann, I864-73.

Brevis historia Sancti Juliani Turonensis. In Recueil de chroniques de Touraine, 220-34.

Caesarius of Heisterbach. Dialogus miraculorum. Edited by Joseph Strange. 2 vols. Cologne: J. M. Herberle (H. Lempertz), I 85 I. 
Cartulaire de Cormery. Edited by J.-J. Bourassé. Mémoires de la Société Archéologique de Touraine 12. Tours: Guilland-Verger, 1861.

Cartulaire de l'abbaye de St. Aubin d'Angers. Edited by Arthur Bertrand de Broussillon. Paris: R. Picard, 1903.

Cartulaire de l'archevêché de Tours. Edited by Louis de Grandmaison. 2 vols. Mémoires de la Société Archéologique de Touraine, 37-38. Tours: Péricat, I 892-94.

Cartulaire de Marmoutier pour le Dunois. Edited by Emile Mabille. Chateaudon: H. Lecesne, I 874 .

Cartulaire de Marmoutier pour le Perche. Edited by M. Barret. Documents sur la Province du Perche, 3d ser., 2. Mortagne: G. Meaux, 1894.

Cartulaire de Marmoutier pour le Vendômois. Edited by M. de Trémault. Paris: Alphonse Picard, I893.

Chartes de Saint-Julien de Tours (1002-1300). Edited by L.-J. Denis. 2 vols. Archives Historiques du Mans 12. Le Mans: Société des Archives Historiques du Maine, 1912-13.

Chronica de gestis consulum Andegavorum. In Chroniques des comtes d'Anjou, 25-73, I35-7I.

Chronicon abbatum Majoris monasterii. In Recueil de chroniques de Touraine, 318-37.

Chronicon Petri filii Bechini. In Recueil de chroniques de Touraine, I-63.

Chronicon rhythmicum Sancti Juliani Turonensis. In Recueil de chroniques de Touraine, 235-56.

Chronicon Turonense abbreviatum. In Recueil de chroniques de Touraine, 162-200.

Chronicon Turonense auctore anonymo canonico Turonensi S. Martini. Edited by Edmond Martène and U. Durand. In Veterum scriptorum et monumentorum historicorum, dogmaticorum, moralium, amplissima collectio, 5:917-1072. 9 vols. Paris: Montalant, 1724-33. Reprint New York: Burt Franklin, 1968.

Consuetudines ecclesiae beati Martini Turonensis. Edited by A. Fl[euret]. Rituel de Saint Martin de Tours. Documents et Manuscrits. Paris: Firmin-Didot, I 899I90I.

Le couronnement de Louis: Chanson de geste du XIIe siècle. Edited by E. Langlois. Paris: Firmin-Didot, I 888.

De antiquis ecclesiae ritibus. Edited by Edmond Martène. 2 d ed. 4 vols. Antwerp: Joannis Baptistae de la Bry, 1736-38. Reprint Hildesheim: Georg Olms, 196769.

"De cultu Sancti Martini apud Turonenses extremo saeculo XII epistolae quatuor." Analecta Bollandiana 3(1884): 217-57. Reedited in Guibert, Abbot of Gembloux, Guiberti Gemblacensis epistolae, 64-102, $128-57$.

“De professionibus abbatum." Edited by Jean Leclercq. "Un traité sur la 'profession des abbés' au XIIe siècle." Studia Anselmiana 50(1962): 182-9I.

De rebus gestis in Majori monasterio saeculo XI. Edited by Jean Mabillon and Luc d'Archery. In Acta sanctorum ordinis Sancti Benedicti, saec. 6, part 2, 395-405. 9 vols. Venice: Coletti and J. Bettinelli, 1733-38. 
De reversione beati Martini a Burgundia tranctatus. Edited by André Salmon. In Supplement aux chroniques de Touraine, 14-34. Tours: Guilland-Verger, 1856.

Eadmer. The Life of Saint Anselm, Archbishop of Canterbury. Edited by Sir Richard Southern. London: T. Nelson, 1962.

English Gilds: The Original Ordinances of More Than One Hundred Early English Gilds. Edited by Toulmin Smith. Early English Text Society 40. London: Oxford University Press, 1870. Reprint, 1963.

English Historical Documents. 2d ed. London: E. Methuen, I98I.

"Ex codice MS. monasterii S. Martini Tornacensis." Edited by Michel Toussaint Chrétien du Plessis. In Histoire de l'église de Meaux, 2:36-39. 2 vols. Paris: Julien-Michel Gandouin et Pierre-François Giffart, I73I.

Exordium magnum ordinis Cisterciensis. PL I 85:2:993-I 198.

Fortunatus, Venantius. Carminum, epistularum, expositionum libri undecim. Edited by F. Leo. In $M G H, A A, 4: 1: 7-270$.

Vita Sancti Martini. Edited by F. Leo. In MGH, $A A$, 4:1:293-370.

Fulk Rechin. Fragmentum historiae Andegavensis. In Chroniques des comtes d'Anjou, 232-38.

Genealogiae comitum Andegavensium. In Chroniques des comtes d'Anjou, 247-50.

Gerbert. Epistolae. PL 139:201-68.

Gesta episcoporum Cameracensis. Edited by L. C. Bethmann. In MGH, SS, 7:40289.

Gregory of Tours. De virtutibus beati Martini episcopi. Edited by B. Krusch. In $M G H$, Scr. rer. mer., 1:2:584-66 I.

Historia Francorum. Edited by W. Arndt. In MGH, Scr. rer. mer., I:I. Translated by Lewis Thorpe as History of the Franks. Harmondsworth, England: Penguin Books, 1974.

Liber in gloria confessorum. Edited by B. Krusch. In MGH, Scr. rer. mer., I:2:744-820.

Gregory the Great. Dialogues. Translated by O. J. Zimmerman. New York: Fathers of the Church, 1959.

Gregory VII. "Trois lettres de Grégoire VII." Edited by Léopold Delisle. Bibliothèque de l'Ecole des Chartes 26(1865):556-6I.

Guibert. Vita Leonis IX papae. In Acta sanctorum, April, 2:648-65.

Guibert, Abbot of Gembloux. "Epistola ad Philippum, archiepiscopum Coloniensem." Edited by Edmond Martène and U. Durand. In Thesaurus novus anecdotorum, 1:606-18. 5 vols. Paris: F. Delaulne, 1717. Reprint New York: Burt Franklin, 1968. Reedited in Guiberti Gemblacensis epistolae, I I I-27.

Guiberti Gemblacensis epistolae. Edited by Albert Derolez. Corpus Christianorum, Continuatio Mediaevalis 66. Turnhout: Brepols, 1988.

Guibert of Nogent. De vita sua. Edited by John Benton. Translated by C. C. Swinton Bland as Self and Society in Medieval France. New York: Harper and Row, 1970. 
Le guide du pèlerin de Saint-Jacques de Compostelle. Edited by Jeanne Vielliard. 3d ed. Macon: Protat Frères, 1963.

Guigo of La Grande Chartreuse. “Consuetudines.” PL i 53:63 I-760.

Herbernus, Archbishop of Tours (attributed). Miracula beati Martini. PL I 29:1035-52.

Hildebert of Lavardin. Carmina miscellanea. PL I7I:I38I-I448.

Vita S. Hugonis Abbatis Cluniacensis. In Recueil des historiens des Gaules, I4:70-7I.

Historia Sancti Florenti Salmurensis. Edited by Paul Marchegay and Emile Mabille. In Chroniques des églises d'Anjou, 2:217-328. 2 vols. Paris: Mme Ve J. Renouard, I 869.

Historia septem dormientium (Majoris monasterii). PL 7I:I IOS-I 8.

Hugh of Fleury. Historia ecclesiastica. Edited by G. Pertz. In MGH, SS, 9:349-53.

Hugh of Rouen. "Contra haereticos libri tres." PL 192:1255-98.

"Hugonis Archidiaconi Turonensi dialogus ad Fulbertum amicum suum de quodam miraculo, quod contigit in translatione Sancti Martini." Edited by Jean Mabillon and Luc d'Archery. In Vetera analecta, 213-17. Paris: Montalant, 1723 .

Innocent III. "Regestorum sive epistolarum liber duodecimus." PL 2 16:9-194. Ivo of Chartres. Epistolae. PL 162:I I-290.

Jacob of Voragine. Legenda aurea. Edited by Th. Graesse. Reprint from 3d ed. (I 890). Osnabrück: Otto Zeller, I965.

Johannis Beleth. Summa de ecclesiasticis officiis. Edited by Herbert Douteil. 2 vols. Corpus Christianorum, Continuatio Mediaevalis 4I-4IA. Turnhout: Brepols, 1976.

John of Marmoutier. Historia Gaufredi ducis Normannorum et comitis Andegavorum. In Chroniques des comtes d'Anjou, I72-23I.

John of Salerno. "Vita Sancti Odonis.” PL 133:43-86. Translated by Gerald Sitwell as St. Odo of Cluny. New York: Sheed and Ward, 1958.

Lanfranc. The Monastic Constitutions. Edited and translated by David Knowles. London: Thomas Nelson, I95I.

Layettes du trésor des chartes. Edited by Alexandre Teulet, Joseph de Laborde, Elie Berger, and $\mathrm{H}$. François Delaborde. 5 vols. Inventaire et Documents Publiés par la Direction des Archives. Paris: Plon-Nurrit, I 863-I909.

Liber de restructione Majoris monasterii. In Recueil de chroniques de Touraine, 343-73.

Liberty, Charity, Fraternity: Lay Religious Confraternities at Bergamo in the Age of the Commune. Introduction by Lester K. Little. Texts edited by Sandro Buzzetti. Smith College Studies in History 5I. Northampton, Mass.: Smith College, 1988.

Marmoutier, Cartulaire Blésois. Edited by Charles Métais. Blois: E. Moreau, I889$9 \mathrm{I}$. 
Maurice of Sully. "Homilie pour la fête de St. Martin." Edited by Albert Lecoy de la Marche. In Saint Martin, 693-94. Tours: Alf red Mame, I88I.

Les miracles de Saint Benôit, écrits par Adrevald Aimoin, André, Raoul Tortaire et Hughes de Sainte Marie, moines de Fleury. Edited by E. de Certain. Paris: Mme Ve J. Renouard, 1858.

Monasticon Anglicanum. Edited by Sir William Dugdale. New edition by John Caley, Henry Ellis, and the Rev. Bulkley Bandinel. 6 vols. in 9. London: Longman, Hurst, Rees, Orme and Brown, I817-30.

Narratio controversiae inter capitulum S. Martini Turonensis et Radulphum ejusdem urbis archiepiscopum. In Recueil des historiens des Gaules, 12:459-61.

Narratio de commendatione Turonicae provinciae. In Recueil de chroniques de Touraine, 294-317.

Notitia seu libellus de tribulationibus, et angustiis, et persecutionibus Majori-monasterio injuste illatis ab archiepiscopis et clericis S. Mauricii Turonensis. In Recueil des historiens des Gaules, 1 4:93-98.

Odo of Cluny. Hymni quatuor. PL 133:513-16.

Sermones quinque. PL 133:709-\$2.

Odo Rigaldus, Archbishop of Rouen. The Register of Eudes of Rouen. Translated by Sydney M. Brown. Edited by Jeremiah F. O'Sullivan. Records of Civilization, Sources and Studies 72. New York: Columbia University Press, 1964.

Orderic Vitalis. Historia ecclesiastica. Edited and translated by Marjorie Chibnall. In The Ecclesiastical History of Orderic Vitalis. 6 vols. Oxford: Clarendon Press, 1969-80.

Othloh of Saint Emmerman. "Liber visionum tum suarum, tum aliorum." $P L$ I46:34I-88.

Papsturkunden in Frankreich. n.s., vol. 5. Edited by Johannes Ramackers. Abhandlungen der Akademie der Wissenschaften in Göttingen, PhilologischHistorische Klasse. 3d ser., 35. Göttingen: Vandenhoeck und Rupreckt, I956.

Paulinus of Perigord. De vita Sancti Martini episcopi libri VI. Edited by M. Petschenig. In Poetae Christiani minores, I:17-159. 2 vols. Corpus Scriptorum Ecclesiasticorum Latinorum I6. Vienna: F. Tempsky, I888.

Péan Gatineau. La vie monseignor Saint Martin de Tors. Edited by Werner Söderhjelm. In Das altfranzösische Martinsleben des Péan Gatineau aus Tours, neue nach der Handschrift revidierte Ausgabe. Helsingfors: Wentzel Hagelstam, 1899. An earlier edition by Söderhjelm is less accurate but has a better introduction: Leben und Wunderthaten des heiligen Martin: Altfranzösisches Gedicht aus dem Anfang des XIII Jahrhunderts von Péan Gatineau aus Tours. Tübingen: Literarischer Verein in Stuttgart, 1896.

Peter Abelard. Epistolae. PL I 78: I 1 3-380.

Peter Comestor. "Sermo ad sacerdotes." Edited by J. P. Bonnes. "Un des plus grands prédicateurs du XIIe siècle, Geoffroy du Loroux dit Geoffroy Babion." Revue Bénédictine 56(1945-46): 174-21 5.

Peter Damian. Epistolae. PL 144:205-498. 
Peter the Chanter. Summa de sacramentis et animae consiliis. Edited by Jean-Albert Dugauquier. 3 vols. in 5 . Analecta Mediaevalia Namurcensia, 4, II, I6, 2 I. Louvain, Lille: Nauwelaerts, I954-67.

Peter the Venerable. De miraculis libri duo. PL I 89:85I-954.

“Dispositio rei familiaris Cluniacensis." PL I 89:1047-54.

The Letters of Peter the Venerable. Edited by Giles Constable. 2 vols. Cambridge: Harvard University Press, 1967.

Statuta Petri Venerabilis. Edited by Giles Constable, with J. D. Brady and D. C. Waddell. In Consuetudines Benedictinae variae, edited by Giles Constable, 19-106. Corpus Consuetudinum Monasticarum 6. Sieburg: Franciscum Schmitt, I975.

"Les prieurés de Marmoutier en Anjou, inventaire des titres et supplements aux chartes des XIc et XIIe siècles." Edited by Paul Marchegay. Archives d'Anjou 2(I853): i-xlviii, I-90.

"Quatre miracles de Saint Martin de Tours." Edited by Hippolyte Delehaye. Analecta Bollandiana 55(1937): 29-48.

Radbod of Utrecht. Carmina. Edited by P. de Winterfeld. In Monumenta Germaniae historica, Poetae Latini medii aevi, 4:1:160-73. Vols. I-. Berlin: Weidmann, I880-I9-.

Libellus de miraculo S. Martini. Edited by O. Holder-Egger. In MGH, SS, I 5:2:1 239-44.

Ralph Glaber. Historiarum libri quinque. Edited by Maurice Prou. In Raoul Glaber, les cinq livres de ses histoires (900-1044). Paris: Alphonse Picard, I 886.

RB 1980: The Rule of Saint Benedict in Latin and English with Notes and Thematic Index. Edited by Timothy Fry. Abridged ed. Collegeville, Minn.: Liturgical Press, $198 \mathrm{I}$.

Recueil des actes de Philippe Auguste, roi de France. Edited by Elie Berger, H.François Delaborde, et al. 4 vols. Chartes et diplomes relatifs à l'histoire de France. Paris: Imprimerie Nationale, 1916-79.

Les registres de Grégoire IX. Edited by Lucien Auvray et al. 4 vols. Bibliothèque des Ecoles Français d'Athènes et de Rome. Paris: Albert Fontemoing, Boccard, I 896-1955.

Rigord. Gesta Philippi Augusti. Edited by H.-François Delaborde. In Oeuvres de Rigord et de Guillaume le Breton. 2 vols. Paris: Librairie Renouard, I882, I885.

Rouleaux des morts du IXe au XVe siècle. Edited by Léopold Delisle. Paris: Mme Ve J. Renouard, I 866.

Sacrorum conciliorum nova et amplissima collectio. Edited by J. D. Mansi. 3 I vols. Florence, etc.: A. Zatta, etc., I759-98.

Select Historical Documents of the Middle Ages. Edited by E. F. Henderson. London: George Bell, I 892.

Sidonius Apollinaris. Poems and Letters. Edited by W. B. Anderson. 2 vols. Cambridge: Harvard University Press, 1956, 1965. 
"Statuts des prieurés de Marmoutier (XIIIe-XIVe siècles)." Edited by Guy Oury. Revue Mabillon 60(1981): I-I6.

Stephen of Fougère. Vita Guilielmi Firmati. In Acta sanctorum, April, 3:334-42.

Sulpicius Severus. Chronica. Edited by C. Halm. In Sulpicii Severi libri qui supersunt, I-IOS. Corpus Scriptorum Ecclesiasticorum Latinorum I. Vienna: C. Geroldi Filium, 1866.

Dialogi. Edited by C. Halm. In Sulpicii Severi libri, I52-216. Translated by Bernard Peebles in Niceta of Remesiana, Writings, Sulpicius Severus, Writings, Vincent of Lérins, Commonitories, Prosper of Aquitaine, Grace and Free Will, I6I25I. Fathers of the Church 7. New York: Fathers of the Church, 1949.

Epistolae. Edited by Jacques Fontaine. In Sulpice Sévère: Vie de Saint Martin, I:316-44. 3 vols. Sources Chrétiennes 133-35. Paris: Cerf, 1967-69. Translated by Peebles, I4I-60 (see above).

Vita Sancti Martini. Edited by Fontaine, I:248-3 16. Translated by Peebles, IOI-40 (see above).

Textus de dedicatione ecclesiae Majoris monasterii. In Recueil de chroniques de Touraine, $338-42$.

Theodoric of Amorbach. Illatio Sancti Benedicti. Edited by Jean Mabillon and Luc d'Archery. In Acta sanctorum ordinis Sancti Benedicti, saec. 4, part 2, 362-67. 9 vols. Venice: Coletti and J. Bettinelli, I733-38.

Thietmar of Merseberg. Chronicon. Edited by Georg Pertz. In MGH, SS, 3:733871 .

Thomais. Vita et martyrium S. Febroniae. In Acta sanctorum, June, s:17-34.

Thomas of Celano. Vita prima S. Francisci Assisiensis. Edited by College of Saint Bonaventura. Analecta Franciscana I0. Quaracchi, Italy: Typographia Collegii S. Bonaventurae, 1926.

Thomas of Chobham. Summa confessorum. Edited by F. Broomfield. Analecta Mediaevalia Namurcensia 25. Louvain: Nauwelaerts, 1968.

Traditio Turonensium de sanguine sanctorum Thebaeorum. In Acta sanctorum, September, 6:384-86. Reedited in Guibert, Abbot of Gembloux, Guiberti Gemblacensis epistolae, 73-75.

Ulrich of Cluny. Antiquiores consuetudines Cluniacensis monasterii. PL 149:643778.

La vie et les miracles de monseigneur Saint Martin. Tours: Mathieu Latheron, 1496. Paris, Bibliothèque Nationale. La Réserve, vélin I I 59.

Vita Radbodi. Edited by O. Holder-Egger. In MGH, SS, I s:I:568-71.

Vita Sancti Martini di anonimo. Edited by Gianvita Resta. Padua: Antenore, 1964.

Walter of Cluny. "De miraculis beatae Virginis Mariae." Edited by Philip Labbe. In Novae bibliothecae manuscript: Librorum tomus primus. Paris: Sebastianum Cramoisy et Gabrielem Cramoisy, 1657.

William Durand (or Durantis). Rationale divinorum officiorum. Naples: J. Dura, I859. 
William of Malmesbury. De gestis regum Anglorum libri quinque. Edited by William Stubbs. 2 vols. Rolls Series. London: Eyre and Spottiswoode, 1887-89.

\section{Secondary Sources}

Abou-El-Haj, Barbara. "The Urban Setting for Late Medieval Church Building: Reims and Its Cathedral between I210 and I 240." Art History II (1988): I7-4 I.

Amore, Agostino, Eugenio Battisti, and Paolo Toschi. "Lucia." In Enciclopedia Cattolica, 8:1618-23. I2 vols. Vatican City: Ente per l'Enciclopedia Cattolica e per il Libro Cattolico, 1949-54.

Amore, Agostino, and Maria Chiara Celletti. "Lucia di Siracusa." In Bibliotheca sanctorum, 8:24I-57. I3 vols. Rome: Istituto Giovanni XXIII della Pontificia Università Lateranense, $196 \mathrm{I}-69$.

Anciaux, Paul. La théologie du sacrement de pénitence au XIIe siècle. Universitas Catholica Lovaniensis, Dissertationes ad Gradum Magistri in Facultate Theologica vel in Facultate Iuris Canonici Consequendum Conscriptae. 2d ser. 4I. Louvain: Nauwelaerts, 1949.

Andrieu, M. Les ordines romani du Haut Moyen Age. 5 vols. Louvain: "Spicilegium Sacrum Lovaniense" Bureaux, 193I-6I.

Anonymous monk of La Grande-Chartreuse. "La doctrine monastique des coutumes de Guigues." Théologie de la Vie Monastique 49(1961): 485-501.

Arbois de Jubainville, $\mathrm{H}$. d'. Histoire des ducs et des comtes de Champagne depuis le VIe siècle jusqu'a la fin du XIe. 6 vols. in 7. Paris: A. Durand, I859-66.

Auerbach, Erich. Mimesis: The Representation of Reality in Western Literature. Translated by Willard R. Trask, 1953. Reprint Princeton: Princeton University Press, 1968.

Bachrach, Bernard S. "The Angevin Stategy of Castle Building in the Reign of Fulk Nerra, 987-I040." American Historical Review 88(1983): 533-60.

"Geoffrey Greymantle, Count of the Angevins, 960-987: A Study in French Politics." Studies in Medieval and Renaissance History [old series 17] 7(1985): 3-67.

Baldwin, John W. The Government of Philip Augustus. Berkeley: University of California Press, 1986.

Masters, Princes and Merchants: The Social Views of Peter the Chanter and His Circle. 2 vols. Princeton: Princeton University Press, 1970.

Baron, Hans. The Crisis of the Early Italian Renaissance. 2 vols. Princeton: Princeton University Press, I955.

Barraclough, Geoffrey. Papal Provisions: Aspects of Church History Constitutional, Legal and Administrative in the Later Middle Ages. Oxford: Basil Blackwell, 1935 .

Bartlett, Robert. Trial by Fire and Water: The Medieval Judicial Ordeal. New York: Oxford University Press, 1986.

Beaune, Colette. Naissance de la nation France. Paris: Gallimard, 1985. 
Becker, Marvin. Medieval Italy: Constraints and Creativity. Bloomington: Indiana University Press, I98I.

Becquet, Jean. "La réforme des chapitres cathédraux en France aux XIc et XIIe siècles." Bulletin Philologique et Historique (jusqu'a 1610) du Comité des Travaux Historiques et Scientifigues, 1977 for 1975, 31-4I.

Benedict, Ruth. The Chrysanthemum and the Sword: Patterns of Japanese Culture. Boston: Houghton Mifflin, 1946.

Benson, Robert. The Bishop-Elect: A Study in Medieval Ecclesiastical Office. Princeton: Princeton University Press, 1968.

"Political Renovatio: Two Models from Roman Antiquity." In Renaissance and Renewal in the Twelfth Century, edited by Giles Constable and Robert L. Benson, 339-86. Cambridge: Harvard University Press, 1982.

Benton, John F. "Consciousness of Self and Perceptions of Individuality." In Renaissance and Renewal in the Twelfth Century, edited by Giles Constable and Robert L. Benson, 263-95. Cambridge: Harvard University Press, 1982.

Berlière, Ursmer. "L'exercice du ministère paroissial par les moines dans le Haut Moyen-Age." Révue Bénédictine 39(1927): 227-50.

—. "Le nombre des moines dans les anciens monastères." Révue Bénédictine 4I(I929); 23 I-6I; 42(I930): I9-42.

Bernstein, Alan. Review of La naissance du purgatoire, by Jacques Le Goff. Speculum 59(1984): 179-83.

Bezzola, R. "De Roland à Raoul de Cambrai." In Mélanges de philologie romane et de littérature médiévale offerts à Emest Hoepffner par ses élèves et ses amis, 195-213. Publications de la Faculté de l'Université de Strasbourg II3. Paris: Belles Lettres, 1949.

Les origines et la formation de la littérature courtoise en Occident (500-1200). Paris: Honoré Champion, 1960.

Bienvenu, Jean-Marc. "La réforme grégorienne dans l'archidiocèse de Tours." In Histoire religieuse de la Touraine, edited by Guy-Marie Oury, 77-91. Chambray: C. L. D. Normand, 1975.

Bishop, Edmund. Liturgica Historica: Papers on the Liturgy and Religious Life of the Westerm Church. Oxford: Clarendon Press, I918. Reprint, I962.

Bloch, Marc. Feudal Society. Translated by L. A. Manyon. 2 vols. Chicago: University of Chicago Press, I96I.

Bloch, R. Howard. Etymologies and Genealogies: A Literary Anthropology of the French Middle Ages. Chicago: University of Chicago Press, 1983.

Medieval French Literature and Law. Berkeley: University of California Press, 1977.

Bolton, Brenda M. "Mulieres Sanctae." In Sanctity and Secularity: The Church and the World, edited by Derek Baker, 77-95. Studies in Church History 10. New York: Barnes and Noble, 1973.

Bonnes, J. P. "Un des plus grands prédicateurs du XIle siècle, Geoffroy du Loroux dit Geoffroy Babion." Revue Bénédictine 56(1945-46): 174-215. 
Bosl, Karl. "Der 'Adelsheilige.' Idealtypus und Wirklichkeit, Gesellschaft und Kultur im merowingerzeitlichen Bayern des 7. und 8. Jahrhunderts." In Speculum historiale: Geschichte im Spiegel von Geschichtsschreibung und Geschichtsdeutung. Festschrift für Johannes Spörl, edited by Clemens Bauer, 167-87. Freiburg/Munich: Alber, 1965.

Bosseboeuf, L. A. “Un missel de Marmoutier du XIe s." Revue de l'Art Chrétien, n.s. 7(1889): 420-33.

Bouchard, Constance. "The Origins of the French Nobility: A Reassessment." American Historical Review 86(198I): 50I-32.

Sword, Miter, and Cloister: Nobility and the Church in Burgundy, 980-1198. Ithaca: Cornell University Press, 1987.

Boureau, Alain. "Les structures narratives de la Legenda aurea: De la variation au grand chant sacré." In Legenda aurea: Sept siècles de diffusion, edited by Brenda Dunn-Lardeau, 57-76. Montreal: Bellarmin, 1986.

Bournazel, Eric, "Suger and the Capetians." In Abbot Sugar and Saint Denis, edited by Paula Lieber Gerson, 55-72. New York: Metropolitan Museum of Art, 1986.

Boussard, Jacques. "L'enclave royale de Saint-Martin de Tours." Bulletin de la Société Nationale des Antiquaires de France, 1985, I 57-79.

. "Essai sur le peuplement de la Touraine du Ier au VIIIe siècle." Moyen Age 60(1954): 26I-9I.

. "Etude sur la ville de Tours du Ier au IVe siècle." Revue des Etudes Anciennes 5o(1948): 313-29.

"Les évêques de Neustrie avant la réforme grégorienne (950-ıoso environ)." Journal des Savants, 1970, 161-96.

"L'éviction des tenants de Thibaut de Blois par Geoffroy Martel, comte d'Anjou en 1044." Moyen Age 69(1963): 141-49.

"La seigneurie de Bellême aux Xe et XIe siècles." In Mélanges d'histoire du Moyen Age dédiés à la mémoire de Louis Halphen, edited by Charles-Edmond Perrin, 43-54. Paris: Presses Universitaires de France, I95I.

"Le trésorier de Saint-Martin de Tours." In Mémorial de l'année martinienne M.DCCCC.LX-M.DCCCC.LXI, 67-88. Paris: J. Vrin, 1962.

Branner, Robert. "Historical Aspects of the Reconstruction of Reims Cathedral, 1210-1241." Speculum 36(1961): 23-37.

Bredero, Adriaan H. "Cluny et le monachisme carolingien: Continuité et discontinuité." In Benedictine Culture, 750-1050, edited by W. Lourdaux and D. Verhelst, 50-75. Louvain: Leuven University Press, 1983.

Bréhier, Louis, and René Aigrain. Grégoire le Grand, les états barbares et la conquête arabe (590-757). In Histoire de l'Eglise depuis les origines jusqu'à nos jours, general editors Augustin Fliche and Victor Martin, volume 5. Paris: Bloud and Gay, 1938.

Brémond, Claude, Jean-Claude Schmitt, and Jacques Le Goff. L'“Exemplum." Typologie des sources du Moyen Age occidental 40. Turnhout: Brepols, 1982. 
Brentano, Lujo. "Preliminary Essay on the History and Development of Gilds, and the Origin of Trade-Unions." In English Gilds, edited by Toulmin Smith, liii-cxciv. Early English Text Society 40. I 870. Reprint London: Oxford University Press, 1963.

Brooke, Rosalind. "The Lives of St. Francis of Assisi." In Latin Biography, edited by T. A. Dorey and Donald R. Dudley. New York: Basic Books, 1967.

Browe, Peter. Die eucharistischen Wunder des Mittelalters. Breslauer Studien zur historischen Theologie, n.s. 4. Breslau: Müller und Seiff ert, 1938.

Brown, Elizabeth A. R. "La notion de la légitimité et la prophétie à la cour de Philippe Auguste." In La France de Philippe Auguste: Le temps des mutations, 77I Io. Colloques internationaux du Centre National de la Recherche Scientifique 602. Paris: CNRS, 1982.

Brown, Peter. The Cult of the Saints: Its Rise and Function in Latin Christianity. Chicago: University of Chicago Press, 198 I.

"Eastern and Western Christendom in Late Antiquity: A Parting of the Ways." In The Orthodox Churches and the West, edited by Derek Baker. Studies in Church History 13. Oxford: Basil Blackwell, 1976.

"Relics and Social Status in the Age of Gregory of Tours." In Society and the Holy in Late Antiquity, 222-50. Berkeley: University of California Press, 1982.

_. "Society and the Supernatural: A Medieval Change." Daedalus I04(1975): I33-5I.

Bur, Michel. La formation du comté de Champagne, v. 950-v. 1150. Mémoires des Annales de l'Est 54. Nancy: Publications de l'Université de Nancy II, 1977.

Bynum, Caroline Walker. Holy Feast and Holy Fast: The Religious Significance of Food to Medieval Women. Berkeley: University of California Press, 1987.

. "Introduction." In Gender and Religion: Essays on the Complexity of Symbols, edited by Caroline Walker Bynum, Stevan Harrell, and Paula Richman, I-20. Boston: Beacon Press, 1986.

Jesus as Mother: Studies in the Spirituality of the High Middle Ages. Berkeley: University of California Press, 1982.

"Religious Women in the Later Middle Ages." In Encyclopedia of World Spirituality, I, edited by Jill Raitt, I2I-39. New York: Crossroad, 1988.

Cabrol, Fernand. "Litanies." In Dictionnaire d'archéologie chrétienne et de liturgie, edited by Fernand Cabrol and Henri Leclercq, 9:2:1540-71. Is vols. Paris: Letouzey et Ané, 1907-53.

Calin, William. The Old French Epic of Revolt: Raoul de Cambrai, Renaud de Montauban, Gormond et Isembar. Geneva: E. Droz, 1962.

Canivez, J.-M. "Arnaud de Bonneval." In Dictionnaire de spiritualité, ascetique et mystique, I:888-90. Paris: G. Beauchesne, I932-.

Catalogue des manuscrits en écriture latine portant des indications de date, de lieu ou de copiste. Charles Samaran and Robert Marichal, general editors. Vols. I-. Paris: Centre National de la Recherche Scientifique, 1959-. 
Catalogue général des manuscrits des bibliothèques publiques de France, départements. Issued by Ministère de l'Education Nationale, Direction des Bibliothèques de France. Paris: Plon, Nourrit, I885-.

Catalogus codicum hagiographicorum Bibliothecae regiae Bruxellensis. 2 vols. Edited by Society of Bollandists. Brussels: Polleunis, Ceuterick et Lefébure, I886, I889.

Catalogus codicum hagiographicorum Latinorum antiquiorum saeculo XVI qui asservantur in Bibliotheca nationali Parisiensi. Edited by Society of Bollandists. 3 vols. Brussels: Society of Bollandists, I 889-93.

Chambers, E. K. The Mediaeval Stage. 2 vols. Oxford: Oxford University Press, 1903.

Chartrou, Josèphe. L'Anjou de 1109 à 1151. Paris: Presses Universitaires de France, 1928.

Chélini, J. "Alcuin, Charlemagne et Saint-Martin de Tours." In Mémorial de l'année martinienne M.DCCCC.LX-M.DCCCC.LXI, 19-50. Paris: J. Vrin, 1962.

Cheney, C. R. Episcopal Visitations of Monasteries in the Thirteenth Century. $2 \mathrm{~d}$ ed. rev. Philadelphia: Porcupine Press, 1983.

Chenu, M.-D. Nature, Man, and Society in the Twelfth Century. Translated by Jerome Taylor and Lester K. Little. Chicago: University of Chicago Press, I968.

Chevalier, Bernard. "La cité de Tours et Châteauneuf du X"e au XIIIe siècle: Note sur l'échec du mouvement communal dans le centre de la France." Cahiers d'Histoire I7(1972): 237-47.

Tours, ville royale, 1356-1520. Louvain: Vander/Nauwelaerts, I975.

Chevalier, Cyr Ulysse Joseph. Repertorium hymnologicum. 6 vols. Sudsidia Hagiographica 4. Louvain, etc.: Lef ever, etc., I892-I 92 I.

Chibnall, Marjorie. The World of Orderic Vitalis. Oxford: Clarendon Press, 1984.

Clanchy, M. T. From Memory to Written Record: England 1066-1307. Cambridge: Harvard University Press, 1979.

Conant, Kenneth J. Benedictine Contributions to Church Architecture. Latrobe, Pa.: Archabbey Press, 1949.

Congar, Yves. "Modèle monastique et modèle sacerdotal en Occident de Grégoire VII (1073-I085) à Innocent III (I 198)." In Etudes de civilisation médiévale (IXe-XII e siècles): Mélanges offerts à Edmond-Réné Labande, I 53-60. Poitiers: Centre d'Études Supérieures de Civilisation Médiévale, I974.

Constable, Giles. Cluniac Studies. London: Variorum Reprints, I980.

“The Monastic Policy of Peter the Venerable." In Pierre Abélard-Pierre le Vénérable, I19-38. Colloques Internationaux du Centre National de la Recherche Scientifique 546. Paris: CNRS, 1975. Reprinted in Constable, Cluniac Studies. London: Variorum Reprints, 1980.

Monastic Tithes: From Their Origins to the Twelfth Century. Cambridge: Cambridge University Press, I964. 
"Papal, Imperial and Monastic Propaganda in the Eleventh and Twelf th Centuries." In Prédication et propagande au Moyen Age: Islam, Byzance, Occident, 79-199. Penn-Paris-Dumbarton Oaks Colloquia 3. Organized by George Makdisi, Dominique Sourdel, and Janine Sourdel-Thomine. Paris: Presses Universitaires de France, 1983.

. "Renewal and Reform in the Religious Life: Concepts and Realities." In Renaissance and Renewal in the Twelfth Century, edited by Giles Constable and Robert L. Benson, 37-67. Cambridge: Harvard University Press, 1982.

Constable, Giles, and Robert L. Benson. "Introduction." In Renaissance and Renewal in the Twelfih Century, edited by Giles Constable and Robert L. Benson, xvii-xxx. Cambridge: Harvard University Press, 1982.

Coornaert, E. "Les ghildes médiévales (Ve-XIVe siècles)." Revue Historique 199(1948): 22-55, 208-43.

Cousin, Patrice. Abbon de Fleury-sur-Loire. Paris: P. Lethiellaux, 1954.

Cowdrey, Herbert Edward John. The Cluniacs and the Gregorian Reform. Oxford: Clarendon Press, 1970.

Crozet, René. "Recherches sur la cathédrale et les évêques de Tours des origines à la fin du XIIe s." Bulletin Trimestriel de la Société Archéologique de Touraine 34(1965): $187-95$.

Curtius, Ernst Robert. European Literature and the Latin Middle Ages. Translated by Willard R. Trask. Princeton: Princeton University Press, 1973.

Danielou, Jean. From Shadows to Reality: Studies in the Biblical Typology of the Fathers. Translated by Dom Wulstan Hibberd. London: Burns and Oates, I960.

Davis, Natalie Zemon. "The Sacred and the Body Social in Sixteenth-Century Lyon." Past and Present 90(198I): 40-70.

Society and Culture in Early Modern France. Stanford: Stanford University Press, 1975.

Delehaye, Hippolyte. "Guibert, Abbé de Florennes et de Gembloux." Revue des Questions Historiques 46(1889): 5-90.

"Saint Martin et Sulpice Sévère." Analecta Bollandiana 38(1920): 5-1 36.

Denton, Jeffrey Howard. English Royal Free Chapels, 1100-1300: A Constitutional Study. Manchester: Manchester University Press, 1970.

Dereine, Charles. "Chanoines." In Dictionnaire d'histoire et de géographie écclesiastiques, 12:353-405. Vols. I-. Paris: Letouzey et Ané, 1912-.

Devailly, Guy. "Expansion et diversité du monachisme du XIc au XIIe siècle." In Histoire religieuse de la Touraine, edited by Guy-Marie Oury, 53-73. Chambray: C. L. D. Normand, 1975 .

Dix, Gregory. The Shape of the Liturgy. London: Dacre Press, 1945.

Dorange, A. Catalogue descriptifet raisonné des manuscrits de la bibliothèque de Tours. Tours: Jules Bouserez, I875.

Dubois, Jacques. Un sanctuaire monastique au Moyen Age: Saint-Fiacre-en-Brie. Paris: Champion, 1976. 
"La vie des moines dans les prieurés du Moyen Age." Lettre de Ligugé 133(1969): 10-33. Reprinted in Dubois, Histoire monastique en France au XII siècle. London: Variorum Reprints, 1982.

Duby, Georges. "Le budget de l'abbaye de Cluny entre I080 et i I55." Annales: Economies, Sociétés, Civilisations 7(1952): I55-77.

"Les chanoines réguliers et la vie économique des XIe et XII e siècles." In La vita comune del clero nei secoli XI e XII, 72-81 Miscellanea del Centro di Studi Medioevali 3. Milan: Società Editrice Vita e Pensiero, 1962.

The Chivalrous Society. Translated by Cynthia Postan. Berkeley: University of California Press, 1980.

The Early Growth of the European Economy: Warriors and Peasants from the Seventh to the Twelfth Century. Translated by Howard B. Clarke. Ithaca: Cornell University Press, 1974.

The Knight, the Lady and the Priest: The Making of Modern Marriage in Medieval France. Translated by Barbara Bray. New York: Pantheon Books, 1983.

Medieval Marriage: Two Models from Twelfth-Century France. Translated by Elborg Forster. Baltimore: Johns Hopkins University Press, 1978.

Rural Economy and Country Life in the Medieval West. Translated by Cynthia Postan. Columbia: University of South Carolina Press, 1968.

The Three Orders: Feudal Society Imagined. Translated by Arthur Goldhammer. Chicago: University of Chicago Press, 1980.

Du Cange, Charles Du Fresne. Glossarium mediae et infimae latinitatis. New edition by Léopold Favre. Io vols. Niort: L. Favre, 1883-87.

Duchesne, Louis. Fastes épiscopaux de l'ancienne Gaule. 3 vols. Paris: A. Fontemoing, 1907-I5.

Origines du culte chrétien: Etude sur la liturgie latine avant Charlemagne. Sth ed., rev. and enl. Paris: Boccard, I925.

Duggan, Lawrence. Bishop and Chapter: The Governance of the Bishopric of Speyer to 1552. New Brunswick, N.J.: Rutgers University Press, 1978.

Dumoutet, Edouard. Corpus Domini: Aux sources de la piété eucharistique médiévale. Paris: Beauchesne, 1942.

Dunbabin, Jean. France in the Making, 843-1180. New York: Oxford University Press, 1985 .

Edwards, Kathleen. The English Secular Cathedrals in the Middle Ages. $2 \mathrm{~d}$ ed. Manchester: Manchester University Press, 1967.

Erdmann, Carl. The Origins of the Idea of Crusade. Translated by Marshall Baldwin and Walter Goffart. Princeton: Princeton University Press, 1977.

Ewig, E. "Le culte de Saint Martin à l'époque franque." In Mémorial de l'année martinienne M.DCCCC.LX-M.DCCCC.LXI, I-18. Paris: J. Vrin, 1962.

Farmer, Sharon. "Persuasive Voices: Clerical Images of Medieval Wives." Speculum 6I(1986): 517-43. 
“Saint Martin's Pentecost: Charisma and Authority in Twelfth-Century Hagiographical Literature." Paper presented at the Spring 1983 meeting of the American Catholic Historical Association.

. "Societal Change and Religious Expression: Saint Martin's Cult at Tours, 1050-1 200.” Ph.D. diss., Harvard University, 1983.

- "Softening the Hearts of Men: Women, Embodiment, and Persuasion in the Thirteenth Century." In Embodied Love: Sensuality and Relationship as Feminist Values, edited by Paula M. Cooey, Sharon A. Farmer, and Mary Ellen Ross, II 5-33. San Francisco: Harper and Row, 1987.

Ferguson, Chris D. "Autobiography as Therapy: Guibert de Nogent, Peter Abelard, and the Making of Medieval Autobiography." Joumal of Medieval and Renaissance Studies I3(1983): 187-212.

Fiske, Adele M. Friends and Friendship in the Monastic Tradition. Cuernavaca, Mexico: Centro Intercultural de Documentación, 1970.

Fliche, Augustin. Le règne de Philippe Ier, roi de France, 1060-1108. Paris: Société Française d'Imprimerie et de Librarie, 1912. Reprint Geneva: SlatkineMegariotis Reprints, 1975.

Folz, Robert. "Pierre le Vénérable et la liturgie." In Pierre Abélard-Pierre le Vénérable, 143-6I. Colloques Internationaux du Centre National de la Recherche Scientifique 546. Paris: CNRS, 1975.

Fontaine, Jacques. Sul pice Sévère: Vie de Saint Martin. 3 vols. Sources Chrétiennes 133-35. Paris: Cerf, 1967-69.

Frank, Roberta. "Viking Atrocity and Skaldic Verse: The Rite of the BloodEagle." English Historical Review 99(1984): 326-44.

Franz, Adolph. Die kirchlichen Benediktionen im Mittelalter. 2 vols. Freiburg-imBreisgau: Herder, 1909.

Frappier, Jean. Les chansons de geste du cycle de Guillaume d'Orange. 2 vols. Paris: Société d'Edition d'Enseignement Supérieur, 1955, 1965.

Freed, John B. The Counts of Falkenstein: Noble Self-Consciousness in TwelfthCentury Germany. Transactions of the American Philosophical Society 74, part 6. Philadelphia: American Philosophical Society, 1984.

Fulton, Rachel. "The Liminal Status of the Excommunicated Monk." Unpublished paper.

Gaiffier, B. de. "Mentalité de l'hagiographie médiévale d'après quelques travaux recents." Analecta Bollandiana 86(1968): 391-99.

"Le trinubium Annae: Haymon d'Halberstadt ou Haymon d'Auxerre?" Analecta Bollandiana 90(1972): 289-98.

Galbraith, V. H. "The Literacy of the Medieval English Kings." Proceedings of the British Academy 21(1937): 201-38.

Galinié, Henri. "La résidence des comtes d'Anjou à Tours." Archéologie Médiévale 7(1977): 95-107.

Galinié, Henri, and Bernard Randoin. Les archives du sol à Tours: Survie et avenir de l'archéologie de la ville. Tours: Société Archéologique de Touraine, 1979. 
Gallia Christiana in provincias ecclesiasticas distributa. $3 \mathrm{~d}$ ed. Edited by Denis de Sainte-Marthe, Benedictines of Saint Maur, and Barthélemy Hauréau. I6 vols. Paris, I7 I 5-I865.

Gantier, Odile. "Recherches sur les possessions et les prieurés de l'abbaye de Marmoutier du Xe au XIIe siècle." Revue Mabillon, 3d ser., 53(1963): 93-I IO, I6I-67; 54(1964): I 5-24, 56-67, 125-35; 55(1965): 32-44, 65-79.

Gasnault, Pierre. "Etude sur les chartes de Saint-Martin de Tours des origines au milieu de XIIe siècle." Positions des Thèses, Ecole Nationale des Chartes, 1953, 37-40.

" $L a$ 'Narratio in reversione beati Martini a Burgundia' du Pseudo-Eudes de Cluny: Sources et influence." Studia Anselmiana 46(196I): I 59-74.

"La sainte ampoule de Marmoutier." Analecta Bollandiana I00(1982): 243-57.

"Le tombeau de Saint Martin et les invasions normandes dans l'histoire et dans la légende." In Mémorial de l'année martinienne M.DCCCC.LX-M.DCCCC.LXI, 5I-66. Paris: J. Vrin, 1962.

Gasté, Armand. "Les drames liturgiques de la cathédrale de Rouen." Revue Catholique de Normandie, 1893, 349-72, 477-500, 573-604.

Gautier, Léon. La chevalerie. New ed. Paris: C. Delagrave, I 890.

Geary, Patrick J. Before France and Germany: The Creation and Transformation of Merovingian Gaul. New York: Oxford University Press, 1988.

"La coercion des saints dans la pratique religieuse médiévale." In $\mathrm{La}$ culture populaire au Moyen Age, edited by Pierre Boglioni, 145-61. Montreal: Aurore, 1979.

Furta Sacra: Thefts of Relics in the Central Middle Ages. Princeton: Princeton University Press, 1978.

"Humiliation of Saints." In Saints and Their Cults: Studies in Religious Sociology, Folklore and History, edited by Stephen Wilson, 123-40. Cambridge: Cambridge University Press, 1983.

"The Ninth-Century Relic Trade: A Response to Popular Piety?" In Religion and the People, 800-1700, edited by James Obelkevich, 8-19. Chapel Hill: University of North Carolina Press, 1979.

Genicot, Léopold. Les généalogies. Typologie des Sources du Moyen Age Occidental is. Turnhout: Brepols, i975.

Giry, Arthur. Les établissements de Rouen: Etudes sur l'histoire des institutions municipales. 2 vols. Paris: F. Vieweg, I883-85. Reprint Geneva: Slatkine, 1975.

Manuel de diplomatique. 2 vols. Paris: Félix Alcan, 1925.

Gold, Penny Schine. The Lady and the Virgin: Image, Attitude, and Experience in Twelfth-Century France. Chicago: University of Chicago Press, I985.

Gougaud, Louis. Anciennes coutumes claustrales. Vienne, France: Abbaye SaintMartin de Ligugé, 1930.

Graham, Rose. "An Appeal, about I I75 for the Building Fund of St. Paul's Cathedral Church." Journal of the British Archaeological Association, 3d ser. IO(I945-47): 73-76. 
Grandmaison, Charles de. Chronique de l'abbaye de Beaumont-lez-Tours. Mémoires de la Société Archéologique de Touraine 26. Tours: Rouillé-Ladevèze, I 877.

Tours archéologique, histoire et monuments. Paris: H. Campion, I 874.

Griffe, Elie. La Gaule chrétienne à l'époque romaine. 3 vols. Paris: Letouzey et Ané, 1964-65.

Griffiths, Quentin. "The Capetian Kings and St. Martin of Tours." Studies in Medieval and Renaissance History [old series 19] 9(1987): 83-133.

Guenée, Bernard. Histoire et culture historique dans l'Occident médiéval. Paris: Aubier Montaigne, 1980.

Guillot, Olivier. Le comte d'Anjou et son entourage au XIe siècle. 2 vols. Paris: A. et J. Picard, 1972.

Haenens, Albert d'. Les invasions normandes en Belgique au IXe siècle. Recueil de Travaux d'Histoire et de Philologie, ser. 4, 38. Louvain: Publications Universitaires de Louvain, 1967.

Les invasions normandes: Une catastrophe? Paris: Flammarion, 1970.

Hallam, Elizabeth. Capetian France, 987-1328. London: Longman House, 1980.

Hallinger, Kassius. Gorze-Kluny: Studien zu den monastischen Lebensformen und Gegensätzen im Hochmittelalter. Studia Anselmiana 22-25. Rome: “Orbis Catholicus," Herder, I950-5I.

Halphen, Louis. Le comté d'Anjou au XIe siècle. Paris: A. Picard, I906. Reprint Geneva: Slatkine-Megariotis Reprints, 1974.

Hanning, Robert. The Vision of History in Early Britain: From Gildas to Geoffrey of Monmouth. New York: Columbia University Press, 1966.

Hautcoeur, Edouard. Histoire de l'église collégiale et du chapitre de Saint-Pierre de Lille. 3 vols. Société d'Études de la Province de Cambrai 4-6. Lille: L. Quarré; Paris: A. Picard, I 896-99.

Head, Thomas. "Andrew of Fleury and the Peace League of Bourges." In Essays on the Peace of God: The Church and the People in Eleventh-Century France, edited by Thomas Head and Richard Landes. Historical Reflections/Réflexions Historiques 14(1987): 513-29.

Hagiography and the Cult of the Saints in the Diocese of Orléans, 800-1200. Cambridge: Cambridge University Press. 1990.

Heath, Robert G. Crux Imperatorum Philosophia: Imperial Horizons of the Cluniac Confratermitas, 964-1109. Pittsburgh: Pickwick Press, 1976.

Heers, Jacques. Fêtes, jeux et joutes dans les sociétés d'Occident à la fin du Moyen Age. Paris: J. Vrin, I97I.

Heinzelmann, Martin. Translationsberichte und andere Quellen des Reliquienkultes. Typologie des Sources du Moyen Age Occidental 33. Turnhout: Brepols, I979.

Herlihy, David. "Land, Family and Women in Continental Europe, 70I-1200." In Women in Medieval Society, edited by Susan Mosher Stuard, 13-45. Philadelphia: University of Pennsylvania Press, 1976.

Medieval Households. Cambridge: Harvard University Press, I985. 
Herrmann-Mascard, Nicole. Les reliques des saints: Formation coutumière d'un droit. Paris: Klincksieck, 1975.

Histoire littéraire de la France. Edited by Benedictines of Saint-Maur and Members of Académie des Inscriptions et Belles-Lettres. 4I vols. Paris: Imprimerie Nationale, 1733-[1981].

Hobsbawm, Eric, and Terence Ranger, eds. The Invention of Tradition. Cambridge: Cambridge University Press, 1983.

Hourlier, Jacques. L'âge classique, 1140-1378: Les religieux. Histoire du Droit et des Institutions de l'Eglise en Occident Io. Paris: Cujas, 1974.

Hourlier, Jacques, and Maria Chiara Celleti. “Maiolo." In Bibliotheca sanctorum, 8:564-67. 13 vols. Rome: Istituto Giovanni XXIII della Pontificia Università Lateranense, 196I-69.

Hughes, Diane Owen. "From Brideprice to Dowry in Mediterranean Europe." Joumal of Family History 3(1978): 262-96.

Huneycutt, Lois. "The Idea of the Perfect Princess: The Life of St. Margaret of Scotland in the Reign of Matilda II (I 100-III8)." Anglo-Norman Studies 12 (1990), 8I-97.

. “Medieval Queenship.” History Today 39(1989): 16-22.

Hunt, Noreen. Cluny under Saint Hugh, 1049-1109. London: E. Arnold, 1967.

Huyghebaert, Nicolas. Les documents nécrologiques. Typologie des Sources du Moyen Age Occidental 4. Turnhout: Brepols, 1972.

"Les femmes laïques dans la vie religieuse des XIe et XIIe siècles dans la province ecclésiastique de Reims." In I laici nella societas christiana dei secoli XI et XII: Atti della terza Settimana internazionale di studio, 346-89. Milan, 1968.

Hyde, J. K. "Medieval Descriptions of Cities." Bulletin of the John Rylands Library 48 (1965-66): 308-40.

Society and Politics in Medieval Italy: The Evolution of the Civil Life, 10001350. New York: St. Martin's Press, 1973.

Imbart de la Tour, Pierre. Les élections épiscopales dans l'église de France du IXe au XIIe siècle. Paris: Hachette, I 890. Reprint Geneva: Slatkine-Megariotis Reprints, 1974.

Jaeger, C. Stephen. The Origins of Courtliness: Civilizing Trends and the Formation of Courtly Ideals, 939-1210. Philadelphia: University of Pennsylvania Press, 1985 .

James, Edwin Oliver. Seasonal Feasts and Festivals. London: Thames and Hudson, 1961 .

Johnson, Penelope D. Prayer, Patronage and Power: The Abbey of La Trinité, Vendôme, 1032-1187. New York: New York University Press, 1981.

Jones, Charles W. Saint Nicholas of Myra, Bari, and Manhattan: Biography of a Legend. Chicago: University of Chicago Press, 1978.

Jordan, William Chester. From Servitude to Freedom: Manumission in the Sénonais in the Thirteenth Century. Philadelphia: University of Pennsylvania Press, 1986. 
Kantorowicz, Ernst H. Laudes Regiae: A Study in Liturgical Acclamations and Medieval Ruler Worship. Berkeley: University of California Press, 1946.

Keane, Mary Michael. "Martin Hymns of the Middle Ages: A Collection and Analysis of Hymns in Honor of Saint Martin of Tours up to c. I300." Ph.D. diss., Catholic University of America, 1968.

Kennedy, V. L. "The Moment of Consecration and Elevation of the Host." Mediaeval Studies 6(1944): 121-50.

King, Archdale A. Liturgies of the Religious Orders. London: Longmans, I955.

Knowles, David. “The Reforming Decrees of Peter the Venerable." In Petrus Venerabilis, 1156-1956, edited by Giles Constable and James Kritzeck, I-20. Studia Anselmiana 40. Rome: Herder, 1956.

Koehler, Erich. "Observations historiques et sociologiques sur la poésie des troubadours." Cahiers de Civilisation Médiévale 7(1964): 27-51.

Koziol, Geoffrey. "Pageants of Renewal: Translations of Saints in the Province of Reims (893-980)." Paper delivered at the December 1987 meeting of the American Historical Association.

Krappe, Alexander. "The Squire's Adventure in Perlesvaus." In Balor with the Evil Eye: Studies in Celtic and French Literature, I14-25. New York: Institut des Etudes Françaises, Columbia University, 1927.

Kretzenbacher, Leopold. Santa Lucia und die Lutzelfrau: Volksglaube und Hochreligion in Spannungsfeld Mittel- und Südosteuropas. Munich: R. Oldenbourg, 1959.

Lackner, Bede K. The Eleventh-Century Background of Cîteaux. Washington, D.C.: Cistercian Publications, 1972.

Landes, Richard. "The Dynamics of Heresy and Reform in Limoges: A Study of Popular Participation in the 'Peace of God' (994-1033)." In Essays on the Peace of God: The Church and the People in Eleventh-Century France, edited by Thomas Head and Richard Landes. Historical Reflections/Réflexions Historiques 14(1987): 467-SII.

Latouche, Robert. The Birth of Western Economy: Economic Aspects of the Dark Ages. Translated by E. M. Wilkinson. New York: Harper Torchbooks, 1966.

Laurent, Jacques. "La prière pour les défunts et les obituaires dans l'ordre de Cîteaux." In Mélanges Saint Bermard, 383-96. XXIVe Congrès de l'Association Bourguignonne de Sociétés Savantes. Dijon: Association des Amis de Saint Bernard, 1953.

Leclercq, Henri. "Chape de Saint Martin." In Dictionnaire d'archéologie chrétienne et de liturgie, 3:1:381-90. Is vols. Paris: Letouzey et Ané, 1907-53.

“Marc (Procession de Saint)." Ibid. I0:2:1740-4I.

“Quatre-temps." Ibid. 14:2:2014-17.

“Tours." Ibid. I 5:2:2570-2677.

Leclercq, Jean. Aux sources de la spiritualité occidentale: Étapes et constantes. Paris: Cerf, I964.

Etudes sur le vocabulaire monastique du Moyen Age. Studia Anselmiana 48. Rome: "Orbis Catholicus," Herder, I96I. 
The Love of Learning and the Desire for God: A Study of Monastic Culture. Translated by Catherine Misrahi. Reprint New York: New American Library of Western Literature, 1962.

Otia monastica: Etudes sur le vocabulaire de la contemplation au Moyen Age. Studia Anselmiana 5I. Rome: “Orbis Catholicus," Herder, I963.

"Recherches sur d'anciens sermons monastiques." Revue Mabillon, 3d ser., 36(1946): I-I 4 .

"Solitude and Solidarity: Medieval Women Recluses." In Medieval Religious Women II: Peaceweavers, edited by Lillian Thomas and John A. Nichols, 67-83. Cistercian Studies 72. Kalamazoo, Mich.: Cistercian Publications, 1987.

“Un traité sur la 'profession des abbés' au XIIe siècle." Studia Anselmiana 50.177-91. Rome: "Orbis Catholicus," Herder, 1962.

Lecoy de la Marche, Albert. Saint Martin. Tours: A. Mame, I88I.

Le Goff, Jacques. "L'apogée de la France urbaine médiévale." In La ville médiévale, edited by Jacques Le Goff, Jacques Rossiaud, and André Chédeville, I 89-405. Histoire de la France Urbaine 2. Paris: Seuil, 1980.

The Birth of Purgatory. Translated by Arthur Goldhammer. Chicago: University of Chicago Press, 1984.

Time, Work, and Culture in the Middle Ages. Translated by Arthur Goldhammer. Chicago: University of Chicago Press, 1980.

Le Goff, Jacques, Jacques Rossiaud, and André Chédeville. La ville médiévale des Carolingiens à la Renaissance. Histoire de la France Urbaine 2. Paris: Seuil, I980.

Lelong, Charles. La basilique Saint-Martin de Tours. Chambray: C. L. D. Normand, 1986.

"Etudes sur l'abbaye de Marmoutier." Bulletin Trimestriel de la Société Archéologique de Touraine 39(1980): 279-320.

“Observations et hypothèses sur l'église abbatiale gothique de Marmoutier." Bulletin Monumental I 38(1980): I I7-71.

"Recherches sur l'abbatiale de Marmoutier à l'époque romane." Académie des Inscriptions et Belles-Lettres, Comptes Rendus des Séances, 1976, 704-34.

Lemarignier, Jean François. Etude sur les privilèges d'exemption et de jurisdiction ecclésiastique des abbayes normandes depuis les origines jusqu'en 1140. Archives de la France Monastique 44. Paris: A. Picard, 1937.

"L'exemption monastique et les origines de la réforme grégorienne." In A Cluny: Congrès scientifique. Fêtes et cérémonies liturgiques en honneur des saints abbés Odon et Odilon, 9-11 juillet 1949, 288-340. Société des Amis de Cluny. Dijon: Bernigaud et Privat, I95I.

"Political and Monastic Structures in France at the End of the Tenth and the Beginning of the Eleventh Century." Translated by Fredric L. Cheyette. In Lordship and Community in Medieval Europe, Selected Readings, edited by Fredric L. Cheyette, I00-127. New York: Holt, Rinehart and Winston, I968.

Leriget, Marthe. Des lois et impôts somptuaires. Montpellier: “Abeille," I9I9. 
Leroquais, Victor. Les bréviaires manuscrits des bibliothèques publiques de France. 5 vols. and volume of plates. Paris: Protat Frères, 1934.

Les sacramentaires et les missels manuscrits des bibliothèques publiques de France. 3 vols. Paris, 1924.

Le Roy Ladurie, Emmanuel. Montaillou: The Promised Land of Error. Translated by Barbara Bray. New York: G. Braziller, 1978.

Lesne, Emile. "Les origines de la prébende." Revue Historique de Droit Français et Etranger, 4th ser. 8(1929): 242-90.

Lévêque, Pierre. "Histoire de l'abbaye de Marmoutier jusqu'au XIe siècle." Positions des thèses: Ecole National des Chartes, 1901, 93-101.

"Trois actes faux ou interpolés des comtes Eudes et Robert et du roi Raoul en faveur de l'abbaye de Marmoutier." Bibliothèque de l'Ecole des Chartes 64(1903): 54-82, 289-305.

Lewis, Andrew W. "Dynastic Structures and Capetian Throne-Right: The Views of Giles of Paris." Traditio 33(1977): 225-52.

Royal Succession in Capetian France: Studies on Familial Order and the State. Harvard Historical Studies 100. Cambridge: Harvard University Press, I98I.

Lex, Léonce. "Eudes, Comte de Blois, de Tours, de Chartes de Troyes et de Meaux (995-1037) et Thibaud, son frère (995-1004)." Mémoires de la Société Académique d'Agriculture, des Sciences, Arts et Belles-Lettres du Département de l'Aube, 3d ser., 28(1891): 191-383.

Little, Lester K. Religious Poverty and the Profit Economy in Medieval Europe. Ithaca: Cornell University Press, 1978.

Lopez, Robert S. The Commercial Revolution of the Middle Ages, 950-1350. Englewood Cliffs, N.J.: Prentice-Hall, 197 I.

Lot, Ferdinand. The End of the Ancient World and the Beginning of the Middle Ages. Translated by Philip and Mariette Leon. New York: Harper, 196I.

Etudes sur le règne de Hugues Capet et la fin du $X^{e}$ siècle. Paris: E. Bouillon, 1903.

Mabille, Emile. Les invasions normandes dans la Loire et les pérégrinations du corps de St. Martin. Paris: Henaux, etc., I 869.

"Notice sur les divisions territoriales et la topographie de l'ancienne province de Touraine." Bibliothèque de l'Ecole des Chartes, 6th ser. 27(1866): $335-83$.

La pancarte noire de Saint-Martin de Tours brulée en 1793 et restituée d'après les textes imprimés et manuscrits. Paris: Librairie de Henaux, 1866.

Mabillon, Jean. Annales ordinis S. Benedicti. 6 vols. Lucca: Typis L. Venturini, 1739-45.

McGuire, Brian Patrick. Friendship and Community: The Monastic Experience, 3501250. Kalamazoo, Mich.: Cistercian Publications, 1988.

McLaughlin, Molly Megan. "Consorting with Saints: Prayer for the Dead in Early Medieval French Society.” Ph.D. diss., Stanford University, I985. 
Marot, Pierre, and Jean-Loup Lemaître. Répertoire des documents nécrologiques français. 2 vols. Recueil des Historiens de la France. Paris: Imprimerie Nationale, I 980.

Martène, Edmond. Histoire de l'abbaye de Marmoutier. Annotated by C. Chevalier. 2 vols. Mémoires de la Société Archéologique de Touraine 24, 25. Tours: Guilland-Verger, I874-75.

Martimort, Aimé Georges. La documentation liturgique de Dom Edmond Martène. Studi e Testi 279. Vatican: Biblioteca Apostolica Vaticana, 1978.

Martin, Henri. "Autour de Thomas Pacitius, prieur de la collégiale de Loches." Bulletin Trimestriel de la Société Archéologique de Touraine 4I(I986): 389-95.

Mas-Latrie, Louis de. Trésor de chronologie d'histoire et de géographie pour l'étude et l'emploi des documents du Moyen Age. Paris: V. Palmé, I889.

Meersseman, Gérard G. Ordo fratermitatis: Confratermite e pietà dei laici nel medioevo. 3 vols. Italia Sacra, Studi e Documenti di Storia Ecclesiastica 24-26. Rome: Herder, 1977.

Mesnard, P. "La collégiale de Saint-Martin à l'époque des Valois." In Mémorial de l'année martinienne M.DCCCC. LX-M.DCCCCLXI, 89-Io0. Paris: J. Vrin, 1962.

Mirot, Léon. Manuel de géographie historique de la France. $2 \mathrm{~d}$ ed. Edited by Albert Mirot. 2 vols. Paris: A. et J. Picard, 1947-50.

Molinier, Auguste. Les obituaires français au Moyen Age. Paris: Imprimerie Nationale, I 890.

Moore, R. I. The Formation of a Persecuting Society: Power and Deviance in Westerm Europe, 950-1250. Oxford: Basil Blackwell, 1987.

Moorman, John. A History of the Franciscan Order. Oxford: Clarendon Press, 1968.

Morris, Colin. The Discovery of the Individual, 1050-1200. New York: Harper and Row, 1972.

Mostert, Marco. The Political Theology of Abbo of Fleury: A Study of the Ideas about Society and Law of the Tenth-Century Monastic Reform Movement. Hilversum: Verloren, 1987.

Muir, Edward. Civic Ritual in Renaissance Venice. Princeton: Princeton University Press, I98I.

Murphy, James. J. Rhetoric in the Middle Ages: A History of Rhetorical Theory from Saint Augustine to the Renaissance. Berkeley: University of California Press, I974.

Murray, Alexander. Reason and Society in the Middle Ages. Oxford: Clarendon Press, 1978.

Mussat, André. Le style gothique de l'ouest de la France, XIIe-XIIIe siècles. Paris: A. et J. Picard, 1963.

Musset, Lucien. Les invasions: Le second assaut contre l'Europe chrétienne (VIIe-XIe siècles). Paris: Presses Universitaires de France, 1965. 
"La renaissance urbaine des $\mathrm{X}^{e}$ et $\mathrm{XI}$ e siècles dans l'ouest de la France: Problèmes et hypothèses de travail." In Etudes de civilisation médiévale, IXeXIIe siècles: Mélanges offerts à Edmond-Réné Labande, 2;563-75. 2 vols. Poitiers: Centre d'Etudes Supérierues de Civilisation Médiévale, 1974.

Neiske, Franz. "Vision und Totengedenken." Frühmittelalterliche Studien: Jahrbuch des Instituts für Frühmittelalterforschung der Universität Münster 20(1986): I 38-85.

Newman, William Mendel. Le domaine royal sous les premiers Capétians (9871180). Paris: Librairie de Recueil Sirey, 1937.

Omont, Henri. "Deux incunables imprimés à Tours le 7 mai I496." Bok-Och Bibliotheks-historiska Studier tellägnade Isak Collijn, I 53-60. Uppsala: Almqvist och Wiksell, I925.

Ong, Walter J. The Presence of the Word: Some Prolegomena for Cultural and Religious History. New Haven: Yale University Press, 1967.

Oury, Guy-Marie. "Culte et liturgie de St. Martin." Ami du Clergé, 8th ser. 44(November 2, 196I): 64I-50.

"L'érémitisme à Marmoutier aux XIe et XIIe siècles." Bulletin Trimestriel de la Société Archéologique de Touraine 33(1963): 319-33.

"L'érémitisme dans l'ancien diocèse de Tours au XIIe siècle." Revue Mabillon 60(1970): 43-92.

"L'idéal monastique dans la vie canoniale: Le bienheureux Hervé de Tours (+1022)." Revue Mabillon 52(1962): I-29.

"Les messes de Saint Martin dans les sacramentaires Gallicans, RomanoFrancs et Milanais." Etudes Grégoriennes 5(1962): 73-97.

"La reconstruction monastique dans l'Ouest: L'abbé Gauzbert de St.Julien de Tours (v. 990-1007)." Revue Mabillon 54(1964): 69-1 24.

"Les sept dormants de Marmoutier: La vocation à la réclusion." Analecta Bollandiana 99(1981): 315-27.

Patin, J.-P. Valery, and Jacques Le Goff. "A propos de la typologie des miracles dans le Liber de miraculis de Pierre le Vénérable." In Pierre Abélard-Pierre le Vénérable, I8I-87. Colloques Internationaux du Centre Nationale de la Recherche Scientifique 546. Paris: CNRS, i975.

Penco, Gregorio. "Il tema dell'Esodo nella spiritualità monastica." In Bibbia e spiritualità, edited by C. Vagaggini, 337-77. Rome: Edizioni Paoline, 1967.

Petit-Dutaillis, Charles. The French Communes in the Middle Ages. Translated by Joan Vickers. Europe in the Middle Ages 6. Amsterdam: North-Holland, 1978.

La monarchie féodale en France et en Angleterre (Xe-XIIIe siècle). Evolution de l'Humanité 29. Paris: A. Michel, I97I.

Pietri, Luce. La ville de Tours du IVe au VIe siècle: Naissance d'une cité chrétienne. Rome: Ecole Française de Rome, 1983.

Plat, Gabriel. L'art de bâtir en France des Romains à l'an 1100. Paris: Editions d'Art et d'Histoire, 1939. 
Poly, Jean-Pierre, and Eric Bournazel. "Couronne et mouvance: Institutions et représentations mentales." In La France de Philippe-Auguste: Le temps des mutations, 217-34. Paris: Centre National de la Recherche Scientifique, 1982.

Prévost, Arthur. "Arnaud, Arnold, et Ernaud de Bonneval." In Dictionnaire d'Histoire et de Géographie Ecclésiastiques, 4:421-23. Vols. I-. Paris: Letouzey et Ané, I9I2-.

Prinz, Friedrich. Frühes Mönchtum im Frankenreich: Kulture und Gesellschaft in Gallien, den Rheinlanden und Bayem am Beispiel der monastischen Entwicklung (4. bis 8. Jahrhundert). Munich: R. Oldenbourg, 1965.

Pycke, Jacques. Le chapitre cathédral Nôtre-Dame de Tournai de la fin du XIe siècle à la fin $d u$ XIIIe siècle: Son organisation, sa vie, ses membres. Recueil de travaux d'histoire et de philologie; ser. 6, fasc. 30. Brussels: Nauwelaerts, 1986.

Rabory, J. Histoire de Marmoutier. Paris, I9I I.

Radding, Charles M. “The Evolution of Medieval Mentalities: A CognitiveStructural Approach." American Historical Review 83(1978): 577-97.

Rainey, Ronald E. “Sumptuary Legislation in Renaissance Florence." Ph.D. diss., Columbia University, 1985.

Ramackers, Johannes. “Analekten zur Geschichte des Reformpapsttums und der Cluniazenser." Quellen und Forschungen aus Italienischen Archiven und Bibliotheken, Herausgegeben vom Preussischen Historischen Institut in Rom 23(193 I-32): 22-52.

Reames, Sherry. The Legenda Aurea: A Reexamination of Its Paradoxical History. Madison: University of Wisconsin Press, 1985.

"Saint Martin of Tours in the Legenda Aurea and Before." Viator: Medieval and Renaissance Studies I2(1981): I 3 I-64.

Remensnyder, Amy. "Bernard of Angers and the Liber Miraculorum Sancte Fidis: Lay and Clerical Perceptions of Miracles." Paper delivered at the March 1987 meeting of the Medieval Association of the Pacific.

Reynolds, Susan. Kingdoms and Communities in Western Europe, 900-1300. Oxford: Clarendon Press, 1984.

Riché, Pierre. "Consequences des invasions normandes sur la culture monastique dans l'Occident franc." In I Normanni e la loro espansione in Europa nell'alto medioevo, 705-2I. Settimane di Studio del Centro italiano di Studi Sull'alto Medioevo 16. Spoleto: Presso la Sede del Centro, 1969.

Robin, Françoise. "Les chapelles seigneuriales et royales françaises au temps de Louis XI." In La France de la fin du XVe siècle: Renouveau et apogée, edited by Bernard Chevalier and Philippe Contamine, 237-52. Paris: Centre National de la Recherche Scientifique, I985.

Robinet, André. "Un conflit entre pouvoir civil and pouvoir ecclésiastique: Voies de faits et voies de droit entre comtes de Blois et abbés de Marmoutier." Bulletin Trimestriel de la Société Archéologique de Touraine 39(1981): 781809.

Romilly, Jacqueline de. Magic and Rhetoric in Ancient Greece. Cambridge: Harvard University Press, 1975. 
Rosenwein, Barbara. Rhinoceros Bound: Cluny in the Tenth Century. Philadelphia: University of Pennsylvania Press, 1982. I9(1977): 307-20.

Rosof, Patricia J. F. "The Anchoress in the Twelf th and Thirteenth Centuries." In Medieval Religious Women II: Peaceweavers, edited by Lillian Thomas and John A. Nichols, 123-43. Cistercian Studies 72. Kalamazoo, Mich.: Cistercian Publications, 1987.

Said, Edward. "On Repetition." In The Literature of Fact: Selected Papers from the English Institute, edited by Angus Fletcher, 135-58. New York: Columbia University Press, 1976.

Santifaller, Leo, ed. Quellen und Forschungen zum Urkunden- und Kanzleiwesen Papst Gregors VII. Studi e Testi 190. Vatican: Biblioteca Apostolica Vaticana, 1957-.

Saxer, Victor. Le culte de Marie Madeleine en Occident: Des origines à la findu Moyen Age. 2 vols. Cahiers d'Archéologie et d'Histoire 3. Paris: Clavreuil, 1959.

Schmitt, Jean-Claude. The Holy Greyhound. Translated by Martin Thom. Cambridge: Cambridge University Press, 1983.

"Jeunes et danse de chevaux de bois: Le folklore méridional dans la littérature des exempla." Cahiers de Fanjeaux I I(1976): 127-58.

—. "Les revenants dans la société féodale." Temps de la Réflexion 3(1982): $285-306$.

Schmitz, Philibert. "L'influence de Saint Benôit d'Aniane dans l'histoire de l'ordre de Saint-Benôit." In Il monachesimo nell'alto medioevo e la formazione della civiltà occidentale, 40I-Is. Settimane di Studio del Centro Italiano di Studi Sull'alto Medioevo 4. Spoleto: Presso la Sede del Centro, 1957.

. "La liturgie de Cluny." In Spiritualità Cluniacense, 85-99. Convegni del Centro di Studi Sulla Spiritualità Medievale 2. Todi: Presso l'Accademia Tudertina, I960.

Sébillot, Paul. Le folk-lore de France. 4 vols. Paris: Librairie Orientale et Américaine, 1904-7.

Semmler, Josef. "Benedictus II: Una regula-una consuetudo." In Benedictine Culture, 750-1050, edited by W. Lourdaux and D. Verhelst, I-49. Louvain: Leuven University Press, I983.

Semmler, Josef, and Heinrich Bacht. "Benedikt von Aniane." In Lexikon des Mittelalters, I:1864-67. Munich: Artemis, 1980-.

Sigal, Pierre-André. "Un aspect du culte des saints: Le châtiment divin aux XIe et XIIe siècles d'après la littérature hagiographique du Midi de la France." Cahiers de Fanjeaux II (1976): 39-59. 1985 .

L'homme et le miracle dans la France médiévale (XIe-XIIe siècle). Paris: Cerf,

"Les voyages de reliques aux onzième et douzième siècles." In Voyage, quête, pèlerinage dans la littérature et la civilisation médiévale. Senefiance 2(1976): 75-104. 
Silvestre, Hubert. "Le problème des faux au Moyen Age." Moyen Age 66(1960): $351-70$.

Sot, Michel. Gesta episcoporum, gesta abbatum. Typologie des Sources du Moyen Age Occidental 37. Turnhout: Brepols, 1981 .

"Historiographie episcopale et modèle familial en Occident au IXe siècle." Annales: Economies, Sociétés, Civilisations 33(1978): 433-49.

Southern, Sir Richard. “Aspects of the European Tradition of Historical Writing: 2. Hugh of St. Victor and the Idea of Historical Development." Transactions of the Royal Historical Society, sth ser. 21(1971): 159-79.

"Aspects of the European Tradition of Historical Writing: 4. The Sense of the Past." Transactions of the Royal Historical Society, sth ser. 23(1973): 24363.

"Between Heaven and Hell." Times Literary Supplement, June I8, I982, $651-52$.

The Making of the Middle Ages. New Haven: Yale University Press, 1953.

Saint Anselm and His Biographer: A Study of Monastic Life and Thought, 1059-c. 1130. Cambridge: Cambridge University Press, 1963.

. Westerm Society and the Church in the Middle Ages. Harmondsworth, England: Penguin Books, 1970.

Spiegel, Gabrielle. The Chronicle Tradition of Saint Denis: A Survey. Brookline, Mass.: Classical Folia Editions, 1978.

"The Cult of St. Denis and Capetian Kingship." Journal of Medieval History I (1975): 43-69. Reprinted in Saints and Their Cults: Studies in Religious Sociology, Folklore, and History, edited by Stephen Wilson, I4I-68. Cambridge: Cambridge University Press, 1983.

"Genealogy: Form and Function in Medieval Historical Narrative." History and Theory: Studies in the Philosophy of History 22(1983): 43-53.

Stancliffe, Clare. St. Martin and His Hagiographer: History and Miracle in Sulpicius Severus. Oxford: Clarendon Press, 1983.

Stock, Brian. The Implications of Literacy: Written Language and Models of Interpretation in the Eleventh and Twelfth Centuries. Princeton: Princeton University Press, 1983 .

"Medieval Literacy, Linguistic Theory and Social Organization." New Literary History 16(1984): 13-29.

Strayer, Joseph. On the Medieval Origins of the Modern State. Princeton: Princeton University Press, 1970.

Talbot, C. H. "The Date and Author of the Riposte." In Petrus Venerabilis, 11561956, 72-80. Studia Anselmiana 40. Rome: “Orbis Catholicus," Herder, 1957.

Teetaert, Amédée. La confession aux laïques dans l'église latine depuis le VIIIe jusqu'au $X I V e$ siècle. Paris: J. Gabalda, 1926.

Tentler, Thomas N. Sin and Confession on the Eve of the Reformation. Princeton: Princeton University Press, 1977. 
Thompson, Stith. Motif-Index of Folk Literature. Rev. and enl. ed. 6 vols. Bloomington: Indiana University Press, 1955-58.

Tierney, Brian. The Crisis of Church and State, 1050-1300. Englewood Cliffs, N.J.: Prentice-Hall, 1964.

Trexler, Richard. Public Life in Renaissance Florence. New York: Academic Press, I980.

Tricard, Jean. "La Touraine d'un Tourangeau au XIIe siècle." In Le métier d'historien au Moyen Age: Etudes sur l'historiographie médiévale, edited by Bernard Guenée, 79-93. Paris: Université de Paris I, Panthéon-Sorbonne, Centre de Recherches sur l'Histoire de l'Occident Médiévale, 1977.

Tubach, Frederic C. Index Exemplorum: A Handbook of Medieval Religious Tales. FF Communications 204. Helsinki: Academia Scientiarum Fennica, 1969.

Turner, Victor. The Forest of Symbols: Aspects of Ndembu Ritual. Ithaca: Cornell University Press, 1967.

Van Dam, Raymond. Leadership and Community in Late Antique Gaul. Berkeley: University of California Press, 1985.

Van den Bosch, J. Capa, basilica, monasterium et le culte de Saint Martin de Tours: Etude lexicologique et sémasiologique. Nijmegen: Dekker en Van de Vegt, 1959.

Van der Straeten, Joseph. Les manuscrits hagiographiques d'Orléans, Tours et Angers. Subsidia Hagiographica 64. Brussels: Société des Bollandistes, 1982.

“Le recueil de miracles de S. Martin attribué à Herberne." Analecta Bollandiana 95(1977): 91-100.

"Le recueil de miracles de S. Martin dans le manuscrit I 77 de Charleville." Analecta Bollandiana 94(1976): 83-94.

Van Dijk, S. A. "Historical Liturgy and Liturgical Studies." Dominican Studies 2(1949): I6I-82.

Van Doren, Rombaut, and Angelo Maria Raggi. “Odilia." In Bibliotheca sanctorum, 9:1 I I0-I6. I 3 vols. Rome: Istituto Giovanni XXIII della Pontificia Università Lateranense, 196I-69.

Van Engen, John. “The 'Crisis of Cenobitism' Reconsidered: Benedictine Monasticism in the Years 1050-1 I 50." Speculum 61(1986): 269-304.

Rupert of Deutz. Berkeley: University of California Press, 1983.

Van Gennep, Arnold. Manuel de folklore français. 3 vols. in 7. Paris: A. et J. Picard, 1937-58.

Vaucelle, Edgar Raphaël. La collégiale de Saint-Martin de Tours des origines à l'avènement des Valois (397-1328). Tours: L. Péricat, 1907.

Vidier, Alexandre Charles Philippe. L'historiographie à Saint-Benôit-sur-Loire et les miracles de Saint Benôit. Paris: A. et J. Picard, 1965.

Vieillard-Troiekouroff, May. Les monuments religieux de la Gaule d'après les oeuvres de Grégoire de Tours. Paris: H. Champion, 1976.

"Le tombeau de S. Martin retrouvé en I860." In Mémorial de l'année martinienne M.DCCCC.LX-M.DCCCC.LXI, ISI-83. Paris: J. Vrin, 1962. 
Vivier, R., and E. Millet, Pour comprendre et visiter Tours (Tours, 1977).

Vodola, Elisabeth. Excommunication in the Middle Ages. Berkeley: University of California Press, 1986.

Vogel, Cyril. "La vie quotidienne du moine en Occident à l'époque de la floraison des messes privées." In Liturgie, spiritualité, cultures, edited by A. M. Triacca and A. Pistoia. Conférences Saint-Serge, XXIXe semaine d'études liturgiques, June 29-July 2, 1982. Rome: C. L. V. Edizioni Liturgiche, 1983 .

Voigt, Karl. Die karolingische Klosterpolitik und der Niedergang des westfränkischen Königtums: Laienäbte und Klosterinhaber. Kirchenrechtliche Abhandlungen 9091. Stuttgart: F. Enke, 1917.

Wallace-Hadrill, J. The Long-Haired Kings. London: Methuen, 1962.

“The Vikings in Francia." In Early Medieval History, 217-36. Oxford: Basil Blackwell, I975.

Ward, Benedicta. Miracles and the Medieval Mind: Theory, Record, and Event, 10001215. Philadelphia: University of Pennsylvania Press, 1982.

Warren, W. L. The Governance of Norman and Angevin England, 1086-1272. Stanford: Stanford University Press, 1987.

Weinstein, Donald, and Rudolph Bell. Saints and Society: The Two Worlds of Western Christendom, 1000-1700. Chicago: University of Chicago Press, 1982.

Weiser, Francis X. Handbook of Christian Feasts and Customs. New York: Harcourt, Brace, 1952.

Weissman, Ronald. Ritual Brotherhood in Renaissance Florence. New York: Academic Press, 1982.

Werner, Karl Ferdinand. Les origines. Histoire de France I. General editor Jean Favier. Paris: Fayard, I984.

"Untersuchungen zur Frühzeit des französischen Fürstentums." Welt als Geschichte I 8(1958): 256-89.

White, Stephen D. Custom, Kinship, and Gifts to Saints: The Laudatio Parentum in Westerm France, 1050-1150. Chapel Hill: University of North Carolina Press, 1988.

Williams, George H. Wilderness and Paradise in Christian Thought. New York: Harper and Row, 1962.

Wilmart, André. "Une riposte de l'ancien monachisme au manifeste de Saint Bernard." Révue Bénédictine 46(1934): 296-344.

Wollasch, Joachim. "Ein cluniacensisches Totenbuch aus der Zeit Abt Hugos von Cluny." Frühmittelalterliche Studien I(1967): 406-43. 1982.

Synopse der cluniacensischen Necrologien. 2 vols. Munich: Wilhelm Fink,

“Die Überlieferung cluniacensischen Totengedächtnisses." Frühmittelalterliche Studien I (1967): 389-40 I. 
Wood, Erika Laquer. "The Politics of Sanctity: The Thirteenth-Century Legal Dispute about St. Eloi's Relics." Ph.D. diss., University of Pennsylvania, 1979.

Young, Karl. The Drama of the Medieval Church. 2 vols. Oxford: Clarendon Press, 1933. 
